\title{
ANTI-MUTAGENIC POTENTIAL OF ALGAL EXTRACTS ON CHROMOSOMAL ABERRATIONS IN ALLIUM CEPA L.
}

\author{
Hoda Anwer Mansour, * Hala Mahfouz and Nesma Maher \\ Botany Department, Faculty of Science, Ain Shams University, Abassia, Cairo, Egypt
}

(Received: December 6, 2016; accepted: March 16, 2017)

In the present study, sodium azide (SA) toxicity and the anti-mutagenic effects of different algal extracts at $0.1 \%$ and $0.2 \%$ concentrations were studied on the mitotic index (MI), chromosomal and nuclear aberrations using Allium cepa L. root assay. Moreover, phytochemical screening of photosynthetic pigments, antioxidants compounds, total antioxidant, DPPH scavenging activity, polysaccharides, and phenolic contents were done for two red seaweeds (Laurencia obtusa (Hudson) Lamouroux and Polysiphonia morrowii Harvey) and for one brown seaweed (Dictyopteris delicatula Lamouroux). Treatment with 300 $\mu \mathrm{g} / \mathrm{ml}$ sodium azide (SA) induced the highest number of aberrations in A. cepa root. A highly significant decrease in the MI appeared after treatment with SA, whereas its value increased following different algal extracts treatments. The highest anti-mutagenic inhibition activity of Dictyopteris delicatula added at $0.2 \%$ concentration was $72.96 \%, 69.84 \%, 56.89 \%$ and $43.59 \%$ with the algal polyphenol, polysaccharide, aqueous and methanol extract treatments, respectively. The different algal extracts minimized the genotoxicity and exhibited anti-mutagenic potential against SA in a dose-dependent manner. Phytochemical studies showed that Dictyopteris delicatula contained the highest total phenol, chlorophyll- $a$ and carotenoid quantity. Moreover it exhibited the highest total antioxidant and DPPH scavenging activities. Total polysaccharides and the weight percentage of sulphated polysaccharides were relatively higher in Polysiphonia morrowii followed by Laurencia obtusa. Hydroquinone and bromophenol were detected only in the studied brown and red seaweeds, respectively. Polysiphonia morrowii and Laurencia obtusa contained the highest quantity of galactose, rhmnose and xylose, while Dictyopteris delicatula contained fucose and mannitol as main monosaccharide units. In conclusion, the studied seaweeds may be considered as rich sources of natural antioxidants. Meanwhile the investigated different algal extracts can minimize the genotoxicity in a dose-dependent manner and exhibit anti-mutagenic potential against the mutagenic substance sodium azide.

Keywords: Algal extracts - antioxidant compounds and activity - anti-mutagenic effects - sodium azide - genotoxicity - Allium cepa L.

\section{INTRODUCTION}

Seaweeds are considered as one of the natural renewable resources. However, they produce a wide variety of chemically active secondary metabolites such as fatty acids, sterols, phenolic compounds, terpenes, enzymes, polysaccharides, alkaloids, flavo-

*Corresponding author; e-mail address: rodynarwan@yahoo.com 
noids, ascorbic acids, glutathione and carotenoids. Recent reports revealed that marine algal extracts, that are rich of natural antioxidant compounds with anti-mutagenic, anti-carcinogenic, anti-genotoxic properties, prevent the deleterious consequences of oxidative stress and improve antioxidant status [10, 23, 46]. This may occur through the direct reaction of these natural algal compounds with reactive oxygen species (ROS) by inactivating, removing them and eventually preventing DNA damages or any carcinogenous changes [42]. In this sense, various bioactive compounds obtained from algae showed different physiological effects on humans and other living organisms that may exert a broad range of biological activities against cancer, tuberculosis, inflammations, and other diseases caused by fungi, bacteria or viruses $[1,42,54]$.

Higher plants are often used in many experimental (test) studies since they are not expensive, can be correlated with other animal test systems, and are easily available $[18,31]$. The cytological analysis with respect to mitotic behavior considered to be one of the most reliable way to estimate the potency of any mutagens such as, for example sodium azide. The main aim of this work using Allium cepa root assay was designed to investigate the anti-mutagenic potential of some marine macro-algal extracts against sodium azide (SA). Also, it was intended to provide a complete picture about some phytochemical constituents of the studied algal species.

\section{MATERIALS AND METHODS}

\section{Algal sampling and identification}

Three macro-algal species were collected from the coastal zone of El-Temsah Lake (Ismailia Governorate, Egypt). The collected algal samples were washed with tap and distilled water to remove the debris and were air dried. Each algal sample was divided into three parts; the first was preserved in freezer for fresh weight analysis, while the second one was shaded air-dried and grounded into fine powder. The third part was preserved in $4 \%$ formalin for identification. Algal identification was based on morphological features determined by microscopical examination, using an Olympus DP SOFT microscope equipped with a Canon Powershot G12 digital camera. Algal samples were identified according to Aleem [3]. Two marine macro-algal samples belonged to Rhodophyta (red algae) and were identified as Laurencia obtusa (Hudson) Lamouroux and Polysiphonia morrowii Harvey, while the third one belonged to Pheaophyta (brown algae) and was identified as Dictyopteris delicatula Lamouroux.

\section{Preparation of seaweed extracts}

Aqueous extract was prepared by mixing $100 \mathrm{~g}$ of dried seaweed powder with one liter of distilled water and homogenized with glass homogenizer. After centrifugation 
at $1200 \times \mathrm{g}$ for $20 \mathrm{~min}$, supernatants were collected and filtered with Whatman No. 1 filter paper followed by $0.22 \mu \mathrm{m}$ pore sized filter (Millipore, filter type GV) to obtain the water soluble extract. The remaining pellets were further mixed with $20 \mathrm{ml}$ of distilled water, homogenized and centrifuged as described above. Finally, all aqueous extracts were stored at $-4{ }^{\circ} \mathrm{C}$ for further experiments.

Methanol, phenol and polysaccharide extracts of seaweed powder $(100 \mathrm{~g})$ were prepared according to Machu et al. [34], Malik and Singh [36] and Naguib [41]. Total phenols, total polysaccharides, weight $\%$ of sulfated polysaccharides, monosaccharides and phenolic acids fractionations (using HPLC analysis) were determined according to A.O.A.C. [5], Blakeney and Mutton [8] and Naguib [41].

\section{Analyses of photosynthetic pigments, antioxidant compounds, DPPH scavenging and total antioxidant activities of algae}

Photosynthetic pigments particularly chlorophyll- $a$, chlorophyll- $b$ and carotenoids were extracted in $80 \%$ acetone and determined spectrophotometrically as recommended by Metzner et al. [38]. Antioxidant compounds (as total phenol, ascorbic acid and glutathione) were estimated according to Namvar et al. [42]. Total antioxidant and DPPH scavenging activities were determined according to the method of Naga and Yukimoto [40].

\section{Anti-mutagenic potential of the extracts}

Definite concentrations $(0.1 \%$ and $0.2 \%)$ of the previously prepared algal extracts were used for the A. cepa L. root (var. Giza 6, kindly supplied by the Agricultural Research Center (ARC), Giza, Egypt) treatment to study their anti-mutagenic effects.

Onion bulbs were grown at room temperature $\left(28 \pm 0.5^{\circ} \mathrm{C}\right)$. When the roots reached length of 2 to $3 \mathrm{~cm}$, they were transferred to the test solutions. For antimutagenic analysis, $25 \mathrm{ml}$ of the algal extracts $(0.1 \%$ and $0.2 \%)$ were applied on the A. cepa root tips for 3 hours which had been previously treated for 3 hours with 300 $\mu \mathrm{g} / \mathrm{ml}$ of sodium azid (a mutagenic substance). SA and distilled water served as positive and negative control, respectively.

\section{Microscopic analysis}

The treated roots were fixed in Carnoy's solution (methanol/glacial acetic acid) for 24 hours. After fixation, roots were kept in $70 \%$ alchol in a refrigerator. Slide preparation and staining with Leucobasic Fuchsin were done according to Darlington and La Cour [14]. The preparations were examined under light microscope, 90 fields were completely analyzed for each concentration. The percentage of mitotic index as 
well as the frequencies of different mitotic abnormalities were determined. Reduction percentage of abnormalities induced by mutagenic substance (R) was calculated using the formula of Barcelos et al. [7] as shown below:

$$
\% \text { of } \mathrm{R}=(\mathrm{A}-\mathrm{B}) /(\mathrm{A}-\mathrm{C}) \times 100
$$

where (A) is the proportion of aberrations induced by a known mutagen, (B) is the proportion of aberrations induced by a test sample (different algal extracts), (C) is the proportion of aberrations induced by a negative control.

\section{Statistical analysis}

Data were subjected to $t$-test and to the analysis of variance (ANOVA) with statistical significance at $\mathrm{p}<0.05$ being tested using the Duncan's Test and Pearson correlation.

\section{RESULTS AND DISCUSSION}

Although the anti-mutagenic potential of algal extracts has been extensively studied and well documented $[34,45,46]$, yet there is no report on the anti-mutagenic effects of algal extracts in plant test systems. Exposure A. cepa root tips to $300 \mu \mathrm{g} / \mathrm{ml}$ of SA for $3 \mathrm{~h}$ induced genotoxicity reflected by the high frequency of different types of chromosomal and nuclear abnormalities (Table 1, Fig. 1). Mitotic index (MI) is an indicator of cell proliferation and can be used to evaluate the level of cytotoxicity of an agent [16]. Moreover, data in Table 1 and Fig. 1-I) show a high decrease in the mitotic index after treatment with SA (1.46\%) as compared to the negative control (7.58\%). Administration of algal extracts to the A. cepa root tips exerted a protective potential against the mito-inhibitory effect of SA. However, MI was significantly increased $(5.27 \%)$ by the treatment with $(0.2 \%)$ polysaccharide extract of Polysiphonia morrowii. Sulfated polysaccharides of algae have a wide range of biological activities including free-radical scavengers, anti-mutagenic, anti-carcinogenic, anti-genotoxic and antioxidants that can prevent the oxidative damages in living organisms [23, $28,48]$.

The most common types of abnormalities observed were stickiness, bridges C-M, disturbed meta-anaphase, lagging chromosomes and micronuclei. Considerable frequency of micronuclei was observed in the cells of mitotic division at interphase especially after treatment with SA [17, 19,37]. The formation of micronuclei is regarded as an induction of mutagenicity and cancer risk $[18,27]$. The present results indicate that the maximum percentages of nuclear and total chromosomal abnormalities reached $9.09 \%$ and $60.00 \%$, respectively, following SA treatment $(300 \mu \mathrm{g} / \mathrm{ml})$ as compared with the negative control $(0.00 \%$ and 0.86$)$. Moreover, the total percentage of abnormalities in the root tip cells of $A$. cepa was significantly decreased by the different treatments of algal extracts (Table 1, Fig. 1-II). Effect of polyphenol 


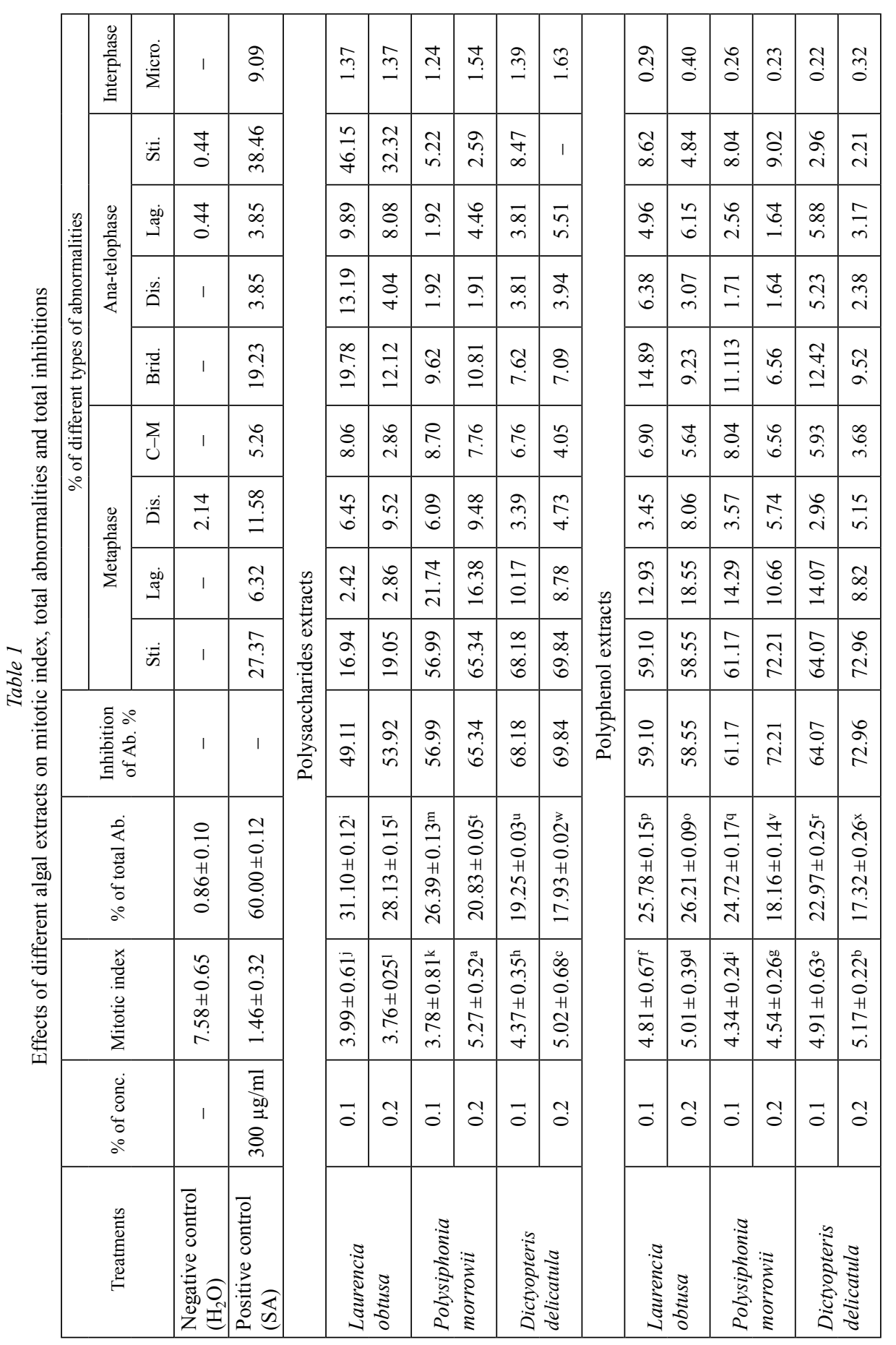




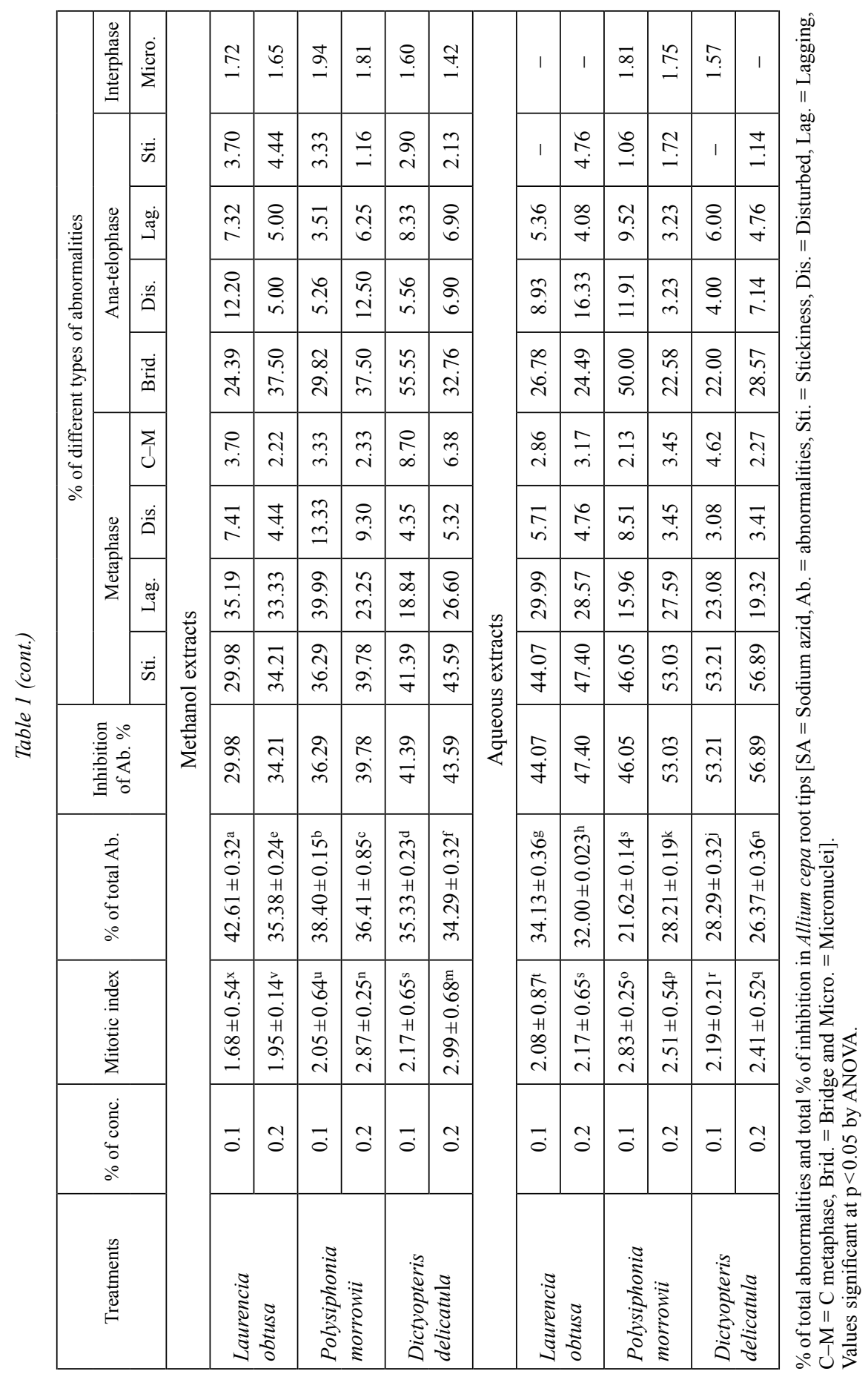

Acta Biologica Hungarica 68, 2017 

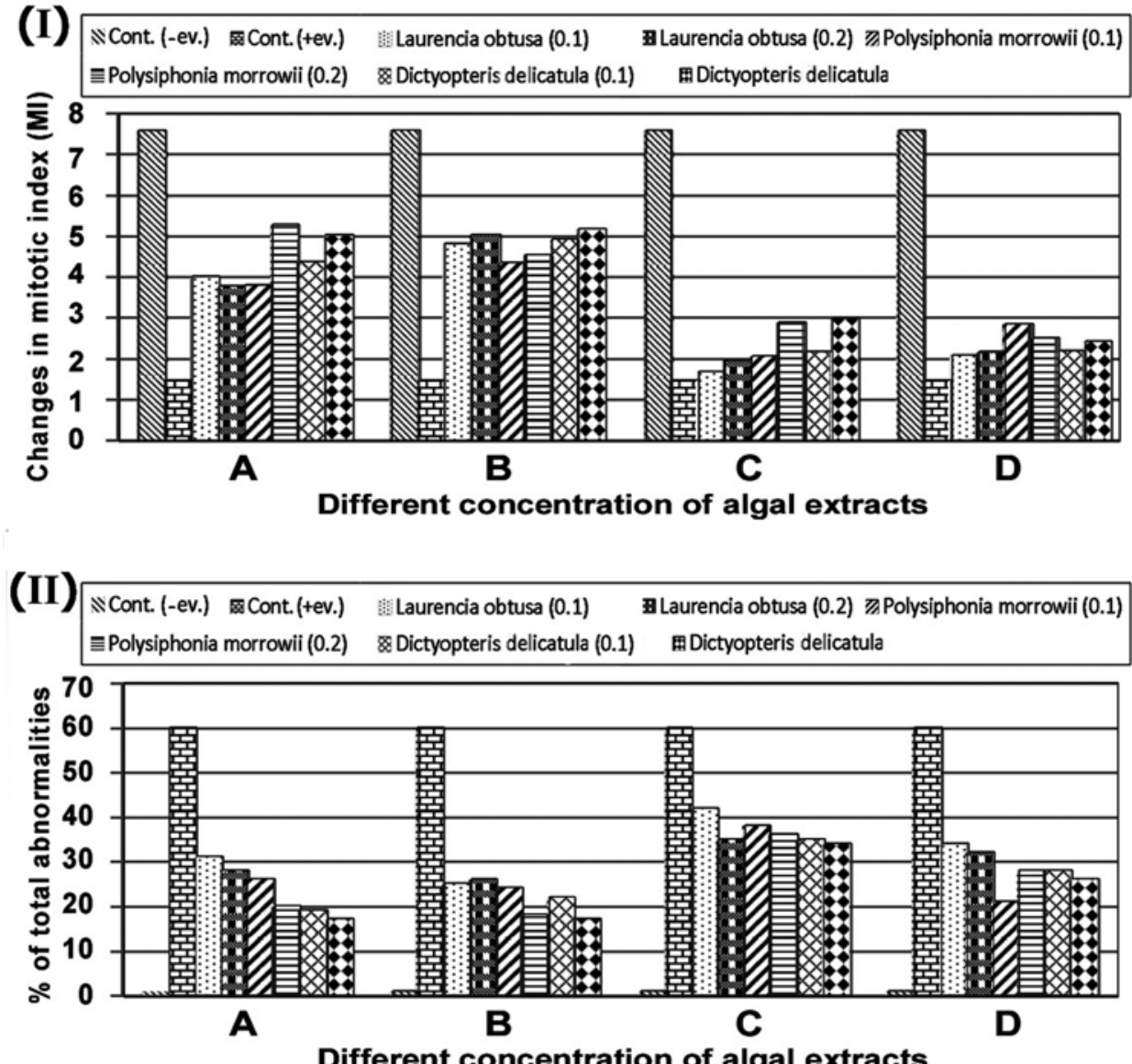

Fig. 1. (I). Changes in the mitotic index (MI) and (II). Frequency of total abnormalities stages after treating Allium cepa root tips (pretreated with SA) with the different concentrations of macro-algal extracts for 3 hours. For (I\& II), A = negative control + positive control + algal polysaccharide extracts; B = negative control+ positive control+algal polyphenol extracts; $\mathrm{C}=$ negative control+ positive control+algal methanol extracts and $\mathrm{D}=$ negative control + positive control + algal aqueous extracts

(17.32\%) and polysaccharide (17.93\%) extracts of Dictyopteris delicatula obtained at $0.2 \%$ alga concentration showed the lowest percentage of total chromosomal aberrations. Additionally, Dictyopteris delicatula at the same concentration showed the highest activity in total abnormalities inhibition $(72.96 \%, 69.84 \%, 56.89 \%$ and $43.59 \%$ ) with the polyphenol, polysaccharide, aqueous and methanol treatments, respectively. The lowest inhibitory effect $(29.98 \%)$ was induced by the $(0.1 \%)$ methanol treatment of Laurencia obtusa. Phenolic compounds were found to be one of the most effective antioxidants and they were reported to have very strong anti-mutagenic properties in brown and red algae [20,24, 28]. 


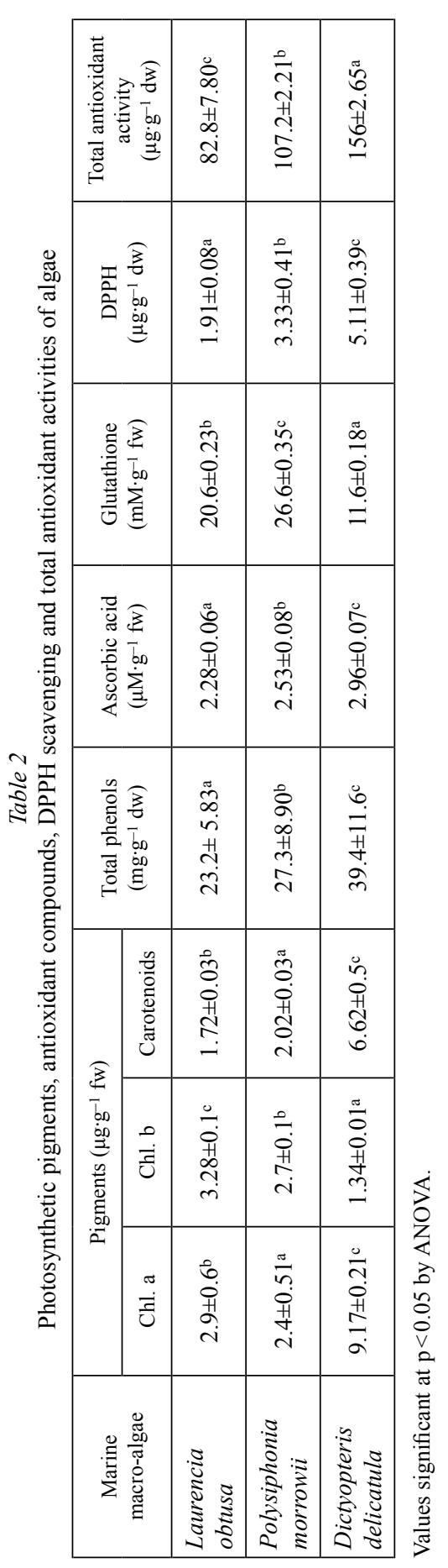

Acta Biologica Hungarica 68, 2017 
Phytochemical screening data shown in Table 2 reveal that chlorophyll- $a$ and carotenoid contents reached their highest values $\left(9.17\right.$ and $6.62 \mu \mathrm{g} \cdot \mathrm{g}^{-1} \mathrm{fw}$, respectively) in Dictyopteris delicatula. Chlorophyll- $b$ had its maximum concentration $\left(3.28 \mu \mathrm{g} \cdot \mathrm{g}^{-1} \mathrm{fw}\right)$ in Laurencia obtusa. According to Christaki et al. [11] and Kumar et al. [26], brown algae are commonly characterized by the highest carotenoid contents. The studied Polysiphonia morrowii and Dictyopteris delicatula species showed a relatively high level of glutathione $\left(26.6 \mu \mathrm{M} \cdot \mathrm{g}^{-1} \mathrm{fw}\right)$, and ascorbic acid (2.96 $\left.\mu \mathrm{M} \cdot \mathrm{g}^{-1} \mathrm{fw}\right)$, respectively, compared to that measured in some higher plants. Our results are in accordance with the findings of Aguilera et al. [2] and Kumar et al. [26]. Moreover, Dictyopteris delicatula exhibited the highest total antioxidant and DPPH scavenging capacities ( 156 and $5.11 \mu \mathrm{g} \cdot \mathrm{g}^{-1} \mathrm{dw}$ respectively), followed by Polysiphonia morrowii (107.2 and $3.33 \mu \mathrm{g} \cdot \mathrm{g}^{-1} \mathrm{dw}$ ) and Laurencia obtusa ( 82.8 and $1.91 \mu \mathrm{g} \cdot \mathrm{g}^{-1} \mathrm{dw}$, respectively. Dictyopteris delicatula was found to possess immense antioxidant potential in the form of total antioxidant, and reduction power activities [9, 33, 35].

Data in Table 2 show significant differences $(\mathrm{p}<0.05)$ in the total phenols contents among the tested Dictyopteris (39.4 $\mathrm{mg} \cdot \mathrm{g}^{-1} \mathrm{dw}$ ), Laurencia and Polysiphonia (23.2 and $27.2 \mathrm{mg} \cdot \mathrm{g}^{-1} \mathrm{dw}$, respectively). Phenolic compounds are potential antioxidants and free-radical scavengers. Brown algae contain, in general, higher amounts of phenolic compounds than red and green algae [48]. Higher antioxidant contents in Dictyopteris may be attributed to its high ascorbic acid, carotenoids and the total phenolic contents $[11,48]$. However, there are a number of studies proving a linear relationship between the total antioxidant capacity and total phenolic contents in algae [34].

Table 3

Area $\%$ of the phenolic acids fractions ( $\mathrm{mg} / 100 \mathrm{~g} \mathrm{dw}$ ) of algae

\begin{tabular}{|l|c|c|c|}
\hline \multirow{2}{*}{\multicolumn{1}{|c|}{ Phenolic acids }} & \multicolumn{2}{|c|}{ Red seaweeds } & Brown seaweed \\
\cline { 2 - 4 } & Laurencia obtusa & $\begin{array}{c}\text { Polysiphonia } \\
\text { morrowii }\end{array}$ & $\begin{array}{c}\text { Dictyopteris } \\
\text { delicatula }\end{array}$ \\
\cline { 2 - 4 } & \multicolumn{3}{|c|}{ (\%) phenolic acids fractions } \\
\hline Cinnamic acid & 0.12 & 0.089 & 0.93 \\
\hline $\begin{array}{l}\text { Isopropyl 3,5-dimethoxy- } \\
\text { 4-hydroxycinnamate }\end{array}$ & 0.05 & N.D. & 0.3 \\
\hline Gallic acid & 0.07 & 0.23 & 1.57 \\
\hline Caffeic acid & 1.2 & 1.5 & 1.09 \\
\hline Coumaric acid & 0.27 & 0.17 & 1.82 \\
\hline Ferulic acid & 0.9 & 0.51 & 0.26 \\
\hline Hydroquinone & N.D. & N.D. & 0.97 \\
\hline $\begin{array}{l}\text { Salicylic acid (methyl- } \\
\text { 4-hydroxy benzoate) }\end{array}$ & N.D. & 0.01 & 0.72 \\
\hline o-Bromophenol & 0.24 & 0.78 & N.D. \\
\hline
\end{tabular}

$($ N.D. $=$ not detected $)$. 
The dominant components of phenolic acids fraction (Table 3) in Dictyopteris were coumaric acid $(1.82 \%)$ followed by gallic $(1.57 \%)$, caffeic acid $(1.09 \%)$, hydroquinone $(0.97 \%)$ cinnamic acid $(0.93 \%)$ and salicylic acid $(0.72 \%)$. The studied red algae were dominated by caffeic, ferulic, $o$-bromophenol and coumaric acid. These were in agreement with the findings of Hsu [22] and Onofrejovaa et al. [44]. Hayat et al. [21] reported that cinnamic acid and some of its esters occur in brown alga Spatoglossum variabile (family: Dictyoaceae). Moreover, our present data show that hydroquinone can be detected only in the studied brown alga species while bromophenol was characteristic for the investigated red seaweeds. This finding is confirmed by the data of Leandrini de Oliveira et al. [28] and Li et al. [30].

The results shown in Table 4 reveal that the studied red weed species (Polysiphonia morrowii and Laurencia obtusa) contain the most monosaccharides sugar galactose, rhamnose and xylose $[12,53]$, whereas Dictyopteris delicatula showed to contain highest area (\%) from fucose followed by mannitol as main monosaccharide units. These are in agreement with the findings of Dai-Hung and Se-Kwon [13], and Li et al. [29]. Total polysaccharides and the weight $\%$ of sulfated polysaccharides dominated in Polysiphonia morrowii (71.1 mg/g DW and 31.07\%), followed by Laurencia obtusa $(37.8 \mathrm{mg} / \mathrm{g}$ DW and 25.7\%) and Dictyopteris delicatula $(28.8 \mathrm{mg} / \mathrm{g} \mathrm{DW}$ and $18.1 \%)$. However, several investigations have reported that sulfated polysaccharides are commonly occurring at high concentrations in red marine algae [52, 55].

Table 4

Area $\%$ of the monosaccharides fractions $(\mathrm{mg} / 100 \mathrm{~g} \mathrm{dw})$, weight $\%$ of sulfated polysaccharides and total poly saccharides of algae

\begin{tabular}{|l|c|c|c|}
\hline \multirow{2}{*}{ Name of sugars } & \multicolumn{2}{|c|}{ Red seaweeds } & Brown seaweed \\
\cline { 2 - 4 } & $\begin{array}{c}\text { Laurencia } \\
\text { obtusa }\end{array}$ & $\begin{array}{c}\text { Polysiphonia } \\
\text { morrowii }\end{array}$ & $\begin{array}{c}\text { Dictyopteris } \\
\text { delicatula }\end{array}$ \\
\hline \multicolumn{3}{|c|}{ (\%) of polysaccharides fractions } \\
\hline Glucose & 22.75 & 24.75 & 8.64 \\
\hline Fructose & 1.36 & 2.09 & 7.61 \\
\hline Arabinose & 0.44 & 0.69 & 0.16 \\
\hline Rhamnose & 50.06 & 58.2 & 9.03 \\
\hline Xylose & 30.3 & 39.53 & 23.50 \\
\hline Mannose & 0.2 & 0.06 & 5.03 \\
\hline Fucose & 0.013 & 0.07 & 41.02 \\
\hline Galactose & 52.07 & 81.15 & 0.41 \\
\hline Mannitol & 0.07 & 0.03 & 39.30 \\
\hline w\% of $\mathrm{SO}_{4}$ & 25.7 & 31.07 & 18.1 \\
\hline $\begin{array}{l}\text { Total } \\
\text { polysaccharides } \\
\text { (mg.g-1 dw) }\end{array}$ & $37.8 \pm 2.71^{\mathrm{b}}$ & $71.1 \pm 0.92^{\mathrm{a}}$ & $28.8 \pm 0.89^{\mathrm{c}}$ \\
\hline
\end{tabular}

Values significant at $\mathrm{p}<0.05$ by ANOVA. 
The estimated biogenic algal compounds such as phenolic acids, polysaccharides, ascorbic acid, glutathione and a significant radical scavenging activities are most likely responsible for the anti-mutagenic effect of the studied algal extracts [15, 29, 47].

\section{CONCLUSIONS}

The present study demonstrates the possible pharmaceutical importance of algae with their chemo-preventive potential in the field of cogency. The investigated different algal extracts of Laurencia obtusa (Hudson) Lamouroux, Polysiphonia morrowii Harvey and Dictyopteris delicatula Lamouroux have the potency to suppress or modulate the mutagenic effect induced by SA in a dose-dependent manner. However, further experiments using different test-systems are required to establish adequate procedures for the biological use of this algal extracts.

\section{REFERENCES}

1. Abdul, Q. A., Choi, R. J., Jung, H. A., Choi, J. S. (2016) Health benefit of fucosterol from marine algae: a review. J. Sci. Food Agric. 96, 1856-1866.

2. Aguilera, J., Dummermuth, A., Karsten, U., Schriek, R., Wiencke, C. (2002) Enzymatic defenses against photo-oxidative stress induced by ultraviolet radiation in Arctic marine macroalgae. Polar Biol. 25, 432-441.

3. Aleem, A. A. (1993) The Marine Algae of Alexandria, University of Alexandria, Alexandria, Egypt.

4. Amer, S. M., Ali, E. M. (1986) Cytological effects of pesticides. XVII. Effect of the insecticide dichlorvas on root mitosis of Vicia faba. Cytologia 51, 21-25.

5. A.O.A.C. (1995) Official Methods of Analysis of the Association of Official Agricultural Chemists. Pub A.O.A.C. Washington D.C., U.S.A.

6. Azuine, M. A., Bhide, S. V. (1992) Chemo-preventive effect of turmeric against stomach and skin tumors induced by chemical carcinogens in Swiss mice. Nutr. Cancer 17, 77-83.

7. Barcelos, G. R. M., Shimabukuro, F., Mori, M. P., Maciel, M. A. M., de Syllos Cólus, I. M. (2007) Evaluation of mutagenicity and anti-mutagenicity of cashew stem bark methanolic extract in vitro. J. Ethnopharmacol. 114, 268-273.

8. Blakeney, A. B., Mutton, L. L. (1980) A simple calorimetric method for the determination of sugars in fruits and vegetables. J. Sci. Food Agric. 31, 889-897.

9. Burritt, D. J., Larkindale, J., Hurd, C. L. (2002) Antioxidant metabolism in the intertidal red seaweed Stictosiphonia arbuscula following desiccation. Planta 215, 829-838.

10. Chojnacka, K., Saeid, A., Witkowska, Z., Tuhy, L. (2012) Biologically active compounds in seaweed extracts - the prospects for the application. The Open Conf. Proceed. J. 3, 20-28.

11. Christaki, E., Bonos, E., Giannenas, I., Florou-Paneri, P. (2013) Functional properties of carotenoids originating from algae. J. Sci. Food and Agri. 93, 5-11.

12. Costa, L. S., Fidelis, G. P., Cordeiro, S. L., Oliveira, R. M., Sabry, D. A. (2010) Biological activities of sulfated polysaccharides from tropical seaweeds. Biomed. Pharmacother. 64, 21-28.

13. Dai-Hung, N., Se-Kwon, K. (2013) Sulfated polysaccharides as bioactive agents from marine algae. Inter. J. Biol. Macromolec. 62, 70-75.

14. Darlington, C. D., La Cour, L. F. (1976) The Handling of Chromosomes, 6th edn. Wiley, New York.

15. El-Din, N. S., El-Sherif, Z. M. (2012) Nutritional value of some algae from the north-western Mediterranean coast of Egypt. J. Appl. Phycol. 24, 613-626. 
16. Elghamery, A. A., Elkholy, M. A., El-Yousse, R. A. (2003) Evaluation of cytological effects of $\mathrm{Zn}^{2+}$ in relation to germination and root growth of Nigella sativa L. and Triticum aestivum L. Mutation Res. 537, 2941.

17. Fernandes, T. C. C., Mazzero, D. E. C., Marin-Morales, M. A. (2007) Mechanism of micronuclei formation in polyploidizated cells of Allium cepa exposed to trifluralin herbicide. Pesticide Biochem. Physiol. 88, 252-259.

18. Fiskesjö, G. (1988) The Allium test - an alternative in environmental studies: the relative toxicity of metal ions. Mutat. Res. 197, 243-260.

19. Gadano, A., Gurni, A., López, P., Ferraro, G., Carballo, M. (2002) In vitro genotoxic evaluation of the medicinal plant Chenopodium ambrosioides L. J. Ethnopharmacol. 81, 11-16.

20. Gupta, S., Abu-Ghannam, N. (2011) Bioactive potential and possible health effects of edible brown seaweeds. Trends. Food Sci. Technol. 22, 315-326.

21. Hayat, S., Atta-Rahman, C. M. I., Khan, K. M., Abbaskhan, A. (2002) Two new cinnamic acid esters from marine brown alga Spatoglossum variabile. Chem. Pharm. Bull. 50, 1297-1299.

22. Hsu, C. Y. (2008) Antioxidant activity of Pyrrosia petiolosa. Fitoterap. 79, 64-66.

23. Hwang, P., Wu, C., Gau, S., Chien, S., Hwang, D. (2010) Antioxidant and immune-stimulating activates of hot water extract from seaweed Saragassum hemiphyllum. J. Marine Sci. Technol. 18. 41-46.

24. Kayalvizhi, K., Subramanian, N. V., Boopathy, S., Kathiresan, K. (2014) Antioxidant properties of brown seaweeds Turbinaria ornata (Turner) J. Agardh, 1848 and Padina tetrastromatica (Hauck). J. Biotechnol. Sci. 2, 29-37.

25. Kim, S. H., Choi, D. S., Athukorala, Y., Jeon, Y. J., Senevirathne, M., Rha, C. K. (2007) Antioxidant activity of sulfated polysaccharides isolated from Sargassum fulvellum. J. Food Sci. Nutr. 12, 65-73.

26. Kumar, N. J. I., Kumar, R. N., Bora, A., Amb, M. K., Chakraborthy, S. (2009) An evaluation of the pigment composition of eighteen marine macro-algae collected from Okha Coast, Gulf of Kutch, India. Our Nat. 7, 48-55.

27. Lamsal, K., Ghimire, B. K., Sharma, P., Ghimirar, A. K., Kim, S. W., Yu, C. Y., Chung, M., Lee, Y. S., Kim, J. S., Shakya, S. R. (2010) Genotoxicity evaluation of the insecticide ethion in root of Allium cepa L. Afr. J. Biotechnol. 9, 4204-4210

28. Leandrini de Oliveira, A. L., Da Silva, D. B., Lopes, N. P., Debonsi, H. M. (2012) Chemical constituents from red algae Bostrychia radicans (Rhodomelaceae): New amides and phenolic compounds. Quim. Nova 35, 2186-2188.

29. Li, B., Lu, F., Wei, X., Zhao, R. (2008) Fucoidan: Structure and bioactivity. Molecules 13, 1671-1695.

30. Li, K., Li, X. M., Nai-Yun, J., Bin-Gui Wang, B. G. (2008) Bromophenols from the marine red alga Polysiphonia urceolata with DPPH radical scavenging activity. J. Nat. Prod. 71, 28-30.

31. Liman, R., Aky1l, D., Eren, Y., Konuk, M. (2010) Testing of the mutagenicity and genotoxicity of metolcarb by using both Ames/Salmonella and Allium test. Chemosphere 80, 1056-1061.

32. Lu, Xi, Z., Chun, E. C., Ting, T., Guo, J. W., Hong, G., Xu, L., Yun, Z., Yuan, W., Cheng, C., Pei, M. H. (2011) Anti-cancer effects of polysaccharide and phycocyanin from Porphyra yezoensis. J. Mar. Sci. Technol. 19, 377-382.

33. Luo, H. Y., Wang, B., Yu, C. G., Qu, Y. L., Su, C. L. (2010) Evaluation of antioxidant activities of five selected brown seaweeds from China. J. Med. Plants Res. 4, 2557-2565.

34. Machu, L., Misurcova, L., Ambrozova, J. V., Orsavova, J., Mlcek, J., Sochor, J., Jurikova, T. (2015) Phenolic content and antioxidant capacity in algal food products. Molecules 20, 1118-1133.

35. Magalhaes, K. D., Costa, L. S., Fidelis, G. P., Oliveira, R. M., Nobre, L. T. D. B., Santos, N. D., Camara, R. B. G., Albuquerque, I. R. L., Cordeiro, S. L., Sabry, D. A. et al. (2011) Anticoagulant, antioxidant and antitumor activities of heterofucans from the seaweed Dictyopteris delicatula. Int. J. Mol. Sci. 12, 3352-3365.

36. Malik, C. P., Singh, M. B. (1980) Plant enzymology and histo-enzymology. Kalyani Publishers. New Delhi.

37. Maruhen, A., Datsch, S., Diego, L. R., Thayná, A. S., Gabriela, M. V., Carlye, N. C., Michele, K., Luciana, P., Grégio, A. (2016) Mutagenicity of two herbicides widely used on soybean crops by the Allium cepa test. Cytotechnol 68, 1215-1222. 
38. Metzner, H., Rau, H., Senger, H. (1965) Uentersuchungen zur Synchronisierbarkeit einzelner Pigment. Mangol Mutanten Von Chloella. Plant 65, 186.

39. Mukherjee, S. P., Choudhuri, M. A. (1983) Implications of water stress-induced changes in the levels of endogenous ascorbic acid and hydrogen peroxide in Vigna seedlings. Physiol. Plant 58, 166-170.

40. Nagai, T., Yukimoto, T. (2003) Preparation and functional properties of beverages made from sea algae. Food Chem. 81, 327-332.

41. Naguib, M. I. (1963) Colorimetric estimation of plant polysaccharides. Z. Zucker., 16, 15-18.

42. Namvar, F., Mohamed, S., Fard, S. G. (2012) Polyphenol-rich seaweed (Eucheuma cottonii) extract suppresses breast tumour via hormone modulation and apoptosis induction. Food Chem. 130, 376382.

43. Nwosu, F., Morris, J., Lund, V. A., Stewart, D., Ross, H. A., McDougall, G. J. (2011) Anti-proliferative and potential anti-diabetic effects of phenolic-rich extracts from edible marine algae. Food Chem, 126, 1006-1012.

44. Onofrejovaa, L., Vašičkovaa, J., Klejdusa, B., Stratil, P., Mišurcovac, L., Kračmar, S. C., Kopecky, B. J., Vaceka, J. (2010) Bioactive phenols in algae: The application of pressurized-liquid and solid-phase extraction techniques. J. Pharm. Biomed. Anal. 51, 464-470.

45. Osama, A. H., Abu Zinadah, W., Khalil, K. B., El Ashmaouil, M. H., Faiza, A., Abou Alsoud, E. M. (2013) Evaluation of the anti-genotoxicity and growth performance impacts of green algae on Mugil cephalus. Life Sci. J, 10, 1543-1554.

46. Osuna-Ruiz, I., López-Saiz, C. M., Burgos-Hernández, A., Velázquez, C., Nieves-Soto, M., HurtadoOliva, M. A. (2016) Antioxidant, anti-mutagenic and anti-proliferative activities in selected seaweed species from Sinaloa, Mexico. Pharm. Biol. 9, 1-15.

47. Sachindra, N. M., Sato, E., Maeda, H., Hosokawa, M., Niwano, Y., Kohno, M., Miyashita, K. (2007) Radical scavenging and singlet oxygen quenching activity of marine carotenoid fucoxanthin and its metabolites. J. Agri. Food Chem. 55, 8516-8522.

48. Schoenwaelder, M. E. A. (2008) The biology of phenolic containing vesicles. Algae 23, 163-175.

49. Shahin, S. A., El-Amoodi, K. H. H. (1991) Induction of numberical chromosomal aberrations during DNA synthesis using fungicides nimrod and rubigan-4 in root tips of Vicia faba L. Mutat Res. 261, 169-176.

50. Sobral, O., Marin-Morales, M. A., Ribeiro, R. (2013) Could contaminant induced mutations lead to a genetic diversity over estimation? Ecotoxicol. doi:10.1007/s10646-013-1079-4.

51. Souza, M. C. R., Marques, C. T., Dore, C. M. G., Silva, F. R. F., Rocha, H. A. O., Leite, E. L. (2007) Antioxidant activities of sulfated polysaccharides from brown and red seaweeds. J. Appl. Phycol. 19, 153-160.

52. Synytsya, A., Kim, W. J., Kim, S. M., Pohl, R., Kvasnicka, F. (2010) Structure and antitumor activity of fucoidan isolated from sporophyll of Korean brown seaweed Undaria pinnatifida. Carbohydr. Polym. 81, 41-48.

53. Usov, A. I. (2011) Polysaccharides of the red algae. Adv. Carbohydr. Chem. Biochem. 65, 115-217.

54. Yvonne, V. Y., Natalie, A. (2006) Antioxidant and anti-proliferative activities of extracts from a variety of edible seaweeds. Food Chem. Toxicol. 44, 1144-1150.

55. Zakaria, N. A., Ibrahim, D., Sulaiman, S. F., Supardy, A. (2011) Assessment of antioxidant activity, total phenolic content and in-vitro toxicity of Malaysian red seaweed, Acanthophora spicifera. J. Chem. Pharm. Res. 3, 182-191. 